\title{
Alkaloids and volatile constituents from the stem of Fusaea longifolia (Aubl.) Saff. (Annonaceae)
}

\author{
J.F. Tavares ${ }^{1}$, J.M. Barbosa-Filho', M.S. da Silva*1, J.G.S. Maia ${ }^{2}$, E.V.L. da-Cunha ${ }^{1,3}$ \\ ${ }^{1}$ Laboratório de Tecnologia Farmacêutica "Delby Fernandes de Medeiros”, Universidade Federal da Paraíba, \\ Caixa Postal 5009, 58051-970, João Pessoa, PB, Brasil. \\ ${ }^{2}$ Departamento de Engenharia Química e de Alimentos, Universidade Federal do Pará, Campus Universitário do \\ Guamá, 66075-900 Belém, PA, Brasil. \\ ${ }^{3}$ Departamento de Farmácia, Universidade Estadual da Paraíba, CCBS, 58100-000, Campina Grande, PB,
} Brasil.

\begin{abstract}
A phytochemical study of the ethanol extract and an extraction of the volatile compounds, performed by means of Clevenger apparatus were carried out with the stem of Fusaea longifolia (Aubl.) Saff. (Annonaceae). The ethanol extract yielded $O$-methylmoschatoline, isolated for the first time in this species, and stepholidine, reported for the first time in genus Fusaea. The structural identification of the alkaloids was made based on the analysis of their NMR spectra. Through the use of GC and GC-MS, two sesquiterpenoids, $\alpha$-cadinol (12.5\%) and spatulenol (12.0\%) were identified as the major constituents of the essential oil.
\end{abstract}

Keywords: Fusaea longifolia, Annonaceae, alkaloids, volatile constituents.

\section{INTRODUCTION}

The family Annonaceae, created by Jussieu in 1789 (Hutchinson, 1973), is comprised by 2.300 species distributed in approximately 130 pantropical genera (Maas et al., 2001). The plants of this family are trees and some times climbing plants are also possible to be found (Hegnauer, 1964). Besides their fruits being most of them edible, the plants are also very used in the folk medicine (Correa, 1984).

Circa 170 alkaloids of the types isoquinoline, protoberberine, aporphine and others were isolated from different genera of the Annonaceae (Leboeuf et al., 1982). From the genus Fusaea, comprised by four species commonly found in the Amazon region (Brummitt, 1992), alkaloids of the types aporphine and oxoaporphine were isolated. The species Fusaea longifolia (synonyms: Annona longifolia Aubl., A. rhombipetala Ruiz \& Pav. ex G. Don, Duguetia longifolia (Aubl.) Baill., Fusaea decurrens R. E. Fr.), popularly known in Northern Brazil as "envira”, “envireira” is a bush or small tree found in the Brazilian states of Acre, Amapá, Amazonas, Maranhão, Mato Grosso and Pará (Chatrou, 1998). A previous phytochemical study with this species reported the occurrence of a mixture constituted by $\beta$-sitosterol and stigmasterol and the alkaloids fuseine and liriodenine (Braz-Filho et al., 1976). The present study reports the isolation of the alkaloids stepholidine (1) and $O$ methylmoschatoline (2), as well as the analysis of the composition of the essential oil from the stem of this species.

\section{MATERIAL AND METHODS}

\section{Plant material}

The botanic material was collected in the Mocambo Reserve in the city of Belém, state of Pará, Brazil August 2002. It was identified by Jorge Oliveira, from the Museu Paraense Emilio Goeldi. A voucher specimen is deposited at the Herbarium (MPEG) in Belém, Pará, Brasil under the number 165435.

\section{Extraction and isolation of the alkaloids}

The stem was dried in an oven with circulating air at the temperature of $40^{\circ} \mathrm{C}$ for three days. Afterwards it was grounded and yielded $1800 \mathrm{~g}$ of the stem powder. This material was humidified with $5 \% \mathrm{NH}_{4} \mathrm{OH}$ and subjected to extraction by maceration with $95 \%$ ethanol for 72 hours. The extractive solution was concentrated under vacuum yielding $200 \mathrm{~g}$ of the crude ethanol extract (CEE). The CEE was treated under mechanical stirring with $3 \% \mathrm{HCl}$ and filtered over Celite. The filtrate (acid solution) was made alkaline with $\mathrm{NH}_{4} \mathrm{OH}$ (to $\mathrm{pH}$ 9-10) and extracted with $\mathrm{CHCl}_{3}$ until obtaining a negative result with Dragendorff's reagent. The chloroform phase after concentration under vacuum yielded a residue weighing $2.0 \mathrm{~g}$ which was called Total Tertiary Alkaloids Fraction (TTAF). TTAF was fractionated on a chromatography column over silica gel using hexane, $\mathrm{CHCl}_{3}$ and methanol, pure or as binary mixtures in crescent polarity gradient as eluents. From this procedure stepholidine (0.00034\%) (1) and $O$-methylmoschatoline $(0.00080 \%)$ (2) were obtained (Figure 1). 
Table 1. NMR data $\left({ }^{1} \mathrm{H}: 200 \mathrm{MHz} ;{ }^{13} \mathrm{C}: 50 \mathrm{MHz}, \mathrm{CDCl}_{3}\right.$, $\left.\delta\right)$ of the alkaloids $\mathbf{1}$ and $\mathbf{2}$

\begin{tabular}{|c|c|c|c|c|}
\hline \multirow[b]{2}{*}{ Carbons } & \multicolumn{4}{|c|}{ Alkaloids } \\
\hline & $\delta_{\mathrm{C}} \mathbf{1}$ & $\delta_{\mathrm{C}} 2$ & $\delta_{\mathrm{H}} \mathbf{1}$ & $\delta_{\mathrm{H}} \mathbf{2}$ \\
\hline \multicolumn{5}{|l|}{$\mathbf{C}$} \\
\hline 1 & - & 156.6 & - & - \\
\hline 2 & 145.0 & 147.5 & - & - \\
\hline 3 & 143.8 & 148.6 & - & - \\
\hline $3 a$ & - & 131.3 & - & - \\
\hline $4 \mathrm{a}$ & 130.5 & - & - & - \\
\hline $6 a$ & - & 145.7 & - & - \\
\hline 7 & - & 182.4 & - & - \\
\hline $7 \mathrm{a}$ & - & 131.6 & - & - \\
\hline $8 \mathrm{a}$ & 128.1 & - & - & - \\
\hline 9 & 141.4 & - & - & - \\
\hline 10 & 143.9 & - & - & - \\
\hline $11 \mathrm{a}$ & - & 134.7 & - & - \\
\hline $11 \mathrm{~b}$ & - & 115.9 & - & - \\
\hline $11 \mathrm{c}$ & - & 123.0 & - & - \\
\hline $12 \mathrm{a}$ & 121.1 & - & - & - \\
\hline $13 b$ & 126.0 & - & - & - \\
\hline \multicolumn{5}{|l|}{$\mathbf{C H}$} \\
\hline 1 & 110.5 & - & $6.80(s)$ & - \\
\hline 4 & 111.4 & 119.3 & $6.57(s)$ & $8.21(d, J=5.2 \mathrm{~Hz})$ \\
\hline 5 & - & 144.8 & - & $8.99(d, J=5.2 \mathrm{~Hz})$ \\
\hline 8 & - & 129.1 & - & $8.56(d d, J=7.7 ; 1.6 \mathrm{~Hz})$ \\
\hline 9 & - & 128.4 & - & $7.55(d t, J=7.7 ; 0.8 \mathrm{~Hz})$ \\
\hline 10 & - & 134.5 & - & $7.76(d t, J=7.7 ; 2.8 \mathrm{~Hz})$ \\
\hline 11 & 108.9 & 127.8 & $6.70(d, J=8.4 \mathrm{~Hz})$ & $9.12(d d, J=7.7 ; 0.6 \mathrm{~Hz})$ \\
\hline 12 & 119.3 & - & $6.62(d, J=8.4 \mathrm{~Hz})$ & - \\
\hline $13 \mathrm{a}$ & 59.1 & - & $3.25(m)$ & - \\
\hline \multicolumn{5}{|l|}{$\mathrm{CH}_{2}$} \\
\hline 5 & 29.1 & - & $3.15 ; 2.58(\mathrm{~m})$ & - \\
\hline 6 & 51.5 & - & $3.17 ; 2.65(m)$ & - \\
\hline 8 & 53.5 & - & $4.20 ; 3.48(d, J=15.6 \mathrm{~Hz})$ & - \\
\hline 13 & 36.2 & - & $3.47 ; 2.57(\mathrm{~m})$ & - \\
\hline \multicolumn{5}{|l|}{$\mathrm{OCH}_{3}$} \\
\hline 1 & - & 61.2 & - & $4.02(s)$ \\
\hline 2 & - & 61.6 & - & $4.09(s)$ \\
\hline 3 & 56.1 & 62.0 & $3.85(s)$ & $4.12(s)$ \\
\hline 9 & 55.0 & - & $3.84(s)$ & - \\
\hline
\end{tabular}


<smiles>COc1cc2c(c(I)c1O)[C@H]1Cc3ccc(O)c(OC)c3CN1CC2</smiles>

(1)<smiles>COc1c(OC)c2c3c(nccc3c1OC)C(=O)c1ccccc1-2</smiles>

(2)

Figure 1. Alkaloids isolated from Fusaea longifolia

\section{Extraction and analysis of the essential oil}

The essential oil was extracted by distillation in a Clevenger-type (Andrade et al., 2003), and analyzed by GC and GC-MS. The volatile components were identified in accordance with their retention indexes (Kovats index) and their mass spectra in comparison with the data bank in the system library (Adams, 2001).

\section{RESULTS AND DISCUSSION}

The ${ }^{13} \mathrm{C}$-APT NMR (50 MHz) obtained in $\mathrm{CDCl}_{3}$ of 1 showed a total of 19 signals which led to the recognition of the hydrogenation pattern of each carbon atom (8 non hydrogenated, 4 methylene, 5 methyne and 2 methoxy). These data suggest a carbon skeleton of a tetrahydroprotoberberine type alkaloid. The ${ }^{1} \mathrm{H}$ NMR (200 MHz) obtained in $\mathrm{CDCl}_{3}$ showed a signal at $\delta_{\mathrm{H}} 4.20$ compatible with the equatorial hydrogen $\mathrm{H}-8$ of this type of alkaloids. All the NMR data in comparison with those found in the literature (Brakuni; Gupta, 1975) led to the conclusion that the substance was indeed stepholidine, which is being reported here for the first time in the genus Fusaea. The complete ${ }^{1} \mathrm{H}$ and ${ }^{13} \mathrm{C}$ NMR data of stepholidine can be found in Table 1.

The ${ }^{13} \mathrm{C}$-APT NMR (50 MHz) of 2 obtained in $\mathrm{CDCl}_{3}$ showed a total of total de 19 signals. Nine were attributed to non hydrogenated carbons, 6 to methyne carbons, 3 to methoxy groups and one at $\delta_{C} 182.4$ attributed to a carbonyl carbon. This hydrogenation pattern is compatible with an oxoaporphine type alkaloid. The ${ }^{1} \mathrm{H}$ NMR spectrum $(200 \mathrm{MHz})$ obtained in $\mathrm{CDCl}_{3}$ showed a signal at $\delta_{\mathrm{H}} 9.12$, which agrees with the literature data for the hydrogen $\mathrm{H}-11$ of this type of alkaloids. These data in comparison with the ones from literature (Harrigan et al., 1994), allowed to propose that substance 2 was $O$-methylmoschatoline, which is being reported here for the first time The complete NMR data of $O$-methylmoschatoline can be found in Table 1.

The GC-MS analysis of the essential oil obtained from the stem of $F$. longifolia, revealed that its main components were sesquiterpenes: [ $\alpha$-cadinol (12.5\%), spathulenol (12.0\%), $\delta$-elemene (4.2\%), $\beta$-elemene (3.8 $\%)$, germacrene D (3.7 \%) and germacrene B (2.9\%)].

The results confirm that Fusaea longifolia is a tipical member of the family Annonaceae (Jumana et al., 2000) and show relative chemotaxonomic significance for the genus Fusaea, Since it is the first time that the alkaloid stepholidine is being reported as isolated from one of its plants.

\section{ACKNOWLEDGEMENTS}

The authors are grateful to Vicente rlos de Oliveira Costa, Laboratório de Tecnologia Farmacêutica, Universidade Federal da Paraíba for acquisition of the NMR spectra and to CNPq for the financial support. Sincere thanks are also due to NAPRALERT.

\section{REFERENCES}

Adams RP 2001. Identification of essential oil components by gás chromatography/quadrupole mass spectroscopy. Allured Publishing Corporation, Illinois, USA.

Andrade EHA, Zoghbi MGB, Maia JGS 2003. Volatiles from Aniba terminalis Ducke. J Essent Oil Res 15: 8182.

Brakuni DS, Gupta S 1975. Opium alkaloids XV: Isolation of stepholidine. J Pharm Sci 64: 1040.

Braz-Filho R, Gabriel SJ, Gomes CMR, Gottlieb OR, Bichara MDGA, Maia JGS 1976. Oxoaporphine alkaloids from Fusaea longifolia and Siparuna guianensis Phytochemistry 15: 1187-1188.

Brummitt RK 1992. Vascular plant - families and genera, Royal Botanic Garden, Kew.

Chatrou LW 1998. Changing genera. Systematic studies in Neotropical and West African Annonaceae. Herbarium division, Utrecht University.

Correa MP 1984. Dicionário das plantas úteis do Brasil e das exóticas cultivadas, Ministério da Agricultura, RJ, p. 315

Harrigan GG, Gunatilaka AAL, Kingston DGI, Chan GW, 
Johnson RK 1994. Isolation of bioactive and other oxoaporphine alkaloids from two Annonaceous plants, Xylopia aethiopica and X. miliusa cf. Banacea. J Nat Prod 57: 68-73.

Hegnauer R 1964. Chemotaxonomie der Pflanzen. Basileia and Suttgart, Birkhause Verlag.

Hutchinson J 1973. The families of flowering plants, Oxford, Clarendon Press.

Jumana S, Asan CM, Rashid MA 2000. Alkaloids from Miliusa velutina. Biochem Syst Ecol 28: 483-485.

Leboeuf M, Cavé A, Bhaaumik PK, Mukherjee B, Mukherjee $\mathrm{R}$ 1982. The phytochemistry of the Annonaceae. Phytochemistry 21: 2783-2813.

Maas PJM, Kamer HMV, Junikka L, Mello-Silva R, Rainer H 2001. Annonaceae from Central-eastern Brazil, Rodriguésia 52: 65-98. 